University of Nebraska - Lincoln

DigitalCommons@University of Nebraska - Lincoln

June 1998

\title{
Redistributing Income Upward Through the Cost-Plus Reimbursement Terms of Subgovernment Contracts
}

\author{
F. Gregory Hayden \\ University of Nebraska-Lincoln, ghayden1@unl.edu \\ Steven R. Bolduc \\ University of Nebraska-Lincoln, BOLDUC@MNSTATE.EDU
}

Follow this and additional works at: https://digitalcommons.unl.edu/econfacpub

Part of the Economics Commons

\begin{abstract}
Hayden, F. Gregory and Bolduc, Steven R., "Redistributing Income Upward Through the Cost-Plus Reimbursement Terms of Subgovernment Contracts" (1998). Economics Department Faculty Publications. 18.

https://digitalcommons.unl.edu/econfacpub/18
\end{abstract}

This Article is brought to you for free and open access by the Economics Department at DigitalCommons@University of Nebraska - Lincoln. It has been accepted for inclusion in Economics Department Faculty Publications by an authorized administrator of DigitalCommons@University of Nebraska - Lincoln. 


\title{
Redistributing Income Upward Through the Cost-Plus Reimbursement Terms of Subgovernment Contracts
}

\author{
F. Gregory Hayden \\ and \\ Steven R. Bolduc
}

This is a case study designed to test the thesis (drawn from political science literature) that the power of "subgovernments" in the United States has decreased and, in particular, claims a demise in the power of the atomic energy subgovernment as one proof for the thesis. The subgovernment approach to explaining policymaking in the United States "is based on the observation that relatively small groups of actors dominate certain sectors of the political system" [Duffy 1997, 4]. One function of such subgovernments is to redistribute income upward through the cost-plus reimbursement terms of government contracts.

The subgovernmental institutions - also referred to as subsystems, iron triangles, or policy monopolies [McCool 1990] - are described as "small, stable groups of actors, both public and private, that dominate policy in specific issue areas" [Duffy 1997, 3]. Robert Duffy characterizes a subgovernmental group as typically consisting of mid-level executive bureaucrats, a committee or commission, and a client group (or special interest group, in McCool [1990]). Each actor or unit associated with a subgovernment can potentially benefit from a program's success either politically or economically. Consequently, because of complementary goals, a policy monopoly emerges that protects the shared interests of the units. Policymaking within this monopoly is characterized by quiet negotiations and compromise. Moreover, policy shifts are usually restricted to incremental changes to avoid attracting the attention of those outside the subgovernment.

The authors are Professor of Economics, University of Nebraska-Lincoln, and Commissioner on the Central Interstate Low-Level Radioactive Waste Compact Commission; and graduate student in Economics, University of Nebraska-Lincoln, respectively. This paper was presented at the annual meeting of the Association for Evolutionary Economics, Chicago, Illinois, January 3-5, 1998. 
To better understand the stability and degree of dominance over the policy process by subgovernments, a distinction has been made about the types of issues over which the subgovernment has jurisdiction. According to Duffy [1997], Temples [1980], and Lowi [1964], distributive issues tend to provide a more stable position of dominance for the subgovernment. Such issues are characterized by (1) government subsides or benefits accruing to a small group, (2) low visibility of actions to those outside the subgovernment, and (3) a high degree of cooperation within the subgovernment.

In his Veblen-Commons Award address, Seymour Melman [1997] emphasized subgovernment power in determining Pentagon expenditures and the consequent upward redistribution of income. The U.S. Department of Energy, with its history of the old Atomic Energy Commission and the current Nuclear Regulatory Commission (NRC), has also been a stronghold of subgovernments.

There is agreement that during the two decades following World War II, the political relationships of commercial nuclear power regulation and subsidization clearly reflected subgovernment dominance. "The Atomic Energy Commission (AEC), the Joint Committee on Atomic Energy (JCAE), and the highly concentrated nuclear power industry formed a classic policy subsystem and exercised a virtual monopoly over the nuclear program. Limited participation, consensus, and stability were the norm" [Duffy 1997, 1-2]. The next 20 years saw significant changes because, by the early 1970 s, nuclear power had become one of the most controversial issues in U.S. politics.

Numerous studies have emphasized the decline of the nuclear subgovernment [Temples 1980; Del Sesto 1979; Campbell 1988; Baumgartner and Jones 1993]. However, as recent U.S. General Accounting Office reports have emphasized, the contractual norm is exorbitant cost-plus contract arrangements for nuclear contractors [GAO 1997]. The system remains largely supportive of the industry. The NRC, like its predecessor the Atomic Energy Commission, "operates in an environment ideally suited for regulatory capture; it regulates the actions of a single centralized industry dominated by a small group of large and powerful firms" [Duffy 1997, 3]. Therefore, as Duffy cautions, "old attitudes, and old policies, die hard" [1997, 3].

What kind of subgovernment process replaced the old subgovernment and allowed continued dominance by the nuclear industry and a continuing lucrative practice of contract arrangements? The particular case studied here found that the nuclear subgovernment was able to maintain its incestuous, and lucrative, relationships by fragmenting the decision process and restructuring it so the opposition was made up of small enclaves of disconnected groups spread across the nation. These local oppositional enclaves are not connected to those who were successfully challenging the nuclear subgovernment in Washington, D.C. The congressional component of the subgovernment changed the institutional process so that more decisions 
were transferred to state governments where the public utilities (which own the nuclear power plants) have always had great power.

\section{Disposal of Low-Level Radioactive Waste}

This case study concerns the multistate Central Interstate Low-Level Radioactive Waste Compact (CIC), whose purpose, as defined by Congress, is to find a means for the disposal of low-level radioactive waste (LLRW). The CIC is made up of the states of Arkansas, Kansas, Louisiana, Nebraska, and Oklahoma. To date, the CIC Commission has approved expenses of approximately $\$ 160$ million without any construction taking place nor any foreseen in the near future.

The real-world context of LLRW in the United States is explained below as (1) the process through which actors in the subgovernment network have functioned to establish an exorbitant cost-plus payment contract so they are paid handsomely, even though additional LLRW facilities are neither needed nor being built; (2) a process of supply and demand working in conjunction with technological advancement to dramatically decrease the annual volume of LLRW; (3) decreasing LLRW waste streams and trend line projections of the waste streams; and (4) excess capacity of commercial disposal facilities.

\section{CIC Subgovernment Network}

The way in which the subgoverment functions to keep lucrative contracts approved can be described in this way: American Ecology Corporation and Bechtel meet with the electric generators to decide upon both an agreement between the generators and the CIC and a contract between the developers and the CIC. The CIC commissioners neither request contract negotiations nor participate in them. When dollar limits in a contract are reached, a new agreement and new contract are presented to the CIC with higher limits that are automatically approved. In the late 1980 s, the generators and developers claimed that the total of preoperational costs to include construction would total about $\$ 41$ million. An agreement and contract were approved consistent with that estimate. However, expenses to date are about $\$ 160$ million. Each time the contractual limit is about to be reached, the agreement and contract have been quickly and quietly renewed. The money (which comes from ratepayers) continues to flow from the generators to the CIC to the developers and their subcontractors.

The agreement between the generators and the CIC is a loan agreement to pay the generators an interest rate of prime plus 6.5 percent [Hayden and Bolduc 1997]. Furthermore, the contract between the developers and the CIC has excessive costplus adders for the developers. The terms of the contract were earlier converted to a 
mathematical formula [Hayden and Bolduc 1997], which yields these percentages of cost-plus for each category of cost:

\begin{tabular}{|c|c|c|}
\hline & $110 \%$ of $\mathrm{A}$ & $A$ is cost of sub-subcontractors without cost-plus contract. \\
\hline+ & $121 \%$ of $\mathrm{B}$ & B is costs of sub-subcontractor with cost-plus contract. \\
\hline+ & $116 \%$ of $\mathrm{C}$ & $\begin{array}{l}\mathrm{C} \text { is Bechtel's operating expenses, exclusive of payroll and } \\
\text { capital costs. }\end{array}$ \\
\hline+ & $291 \%$ of $\mathrm{D}$ & D is Bechtel's home-office payroll. \\
\hline+ & $233 \%$ of $E$ & $\mathrm{E}$ is Bechtel's non-home-office payroll. \\
\hline+ & $116 \%$ of $\mathrm{F}$ & $\mathrm{F}$ is Bechtel's capital equipment bought by CIC. \\
\hline+ & G & $\begin{array}{l}\mathrm{G} \text { is stipulated sum or unit-cost contracts awarded by } \\
\text { Nebraska DEQ. }\end{array}$ \\
\hline+ & $(1+a)$ of $\mathrm{H}$ & $\mathrm{H}$ is cost-plus contracts awarded by Nebraska DEQ. \\
\hline+ & DEQ & DEQ is in-house costs of Nebraska DEQ. \\
\hline+ & $105 \%$ of I & I is stipulated sum or unit-cost contracts awarded by DEQ. \\
\hline+ & $108 \%$ of $\mathrm{J}$ & $\begin{array}{l}\mathrm{J} \text { is AEC's operating expenses exclusive of payroll and } \\
\text { capital costs. }\end{array}$ \\
\hline+ & $258 \%$ of $\mathrm{K}$ & $\mathrm{K}$ is AEC's home-office payroll. \\
\hline+ & $210 \%$ of $\mathrm{L}$ & $\mathrm{L}$ is AEC's non-home-office payroll. \\
\hline+ & $108 \%$ of $\mathrm{M}$ & $\mathrm{M}$ is $\mathrm{AEC}$ capital equipment bought by $\mathrm{CIC}$. \\
\hline+ & $\mathbf{N}$ & $\mathrm{N}$ is lobbying and extraordinary legal expenses of AEC. \\
\hline
\end{tabular}

Such excessive cost-plus coefficients do not indicate a subgovernment in demise. In addition, it should be clarified that the developers, not the $\mathrm{CIC}$, determine the basic costs to which the excessive coefficients are added. The costs themselves are incurred without monitoring or field auditing by the CIC or any government organization.

\section{Supply and Demand and Technological Advancements}

As will be documented below, the LLRW volumes generated for disposal have decreased precipitously since 1980 and are continuing to fall due to technological change and market forces. Because disposal prices are based largely on volume, there is a major incentive for generators to use supercompaction and other volumereduction techniques. Shippers are sending the same amount of radioactivity in fewer packages, dramatically reducing volume and extending capacity of existing 
disposal facilities. These trends are likely to continue because of monetary incentives.

The demand for disposal has been decreased through waste-reduction technologies applied by the waste generators. At the same time, costs of disposal have increased, which shifts the supply function upward and decreases the quantity supplied at each price. There is a much smaller quantity of waste-disposal capacity being utilized, but at a higher price. The revenues of the facility owners are down, yet because price is higher, we can expect generators to continue to decrease demand through the application of volume-reducing technologies.

\section{LLRW Streams in United States and CIC Compact}

The analysis above explains conceptually why waste volumes have been decreasing. The empirical results are found in Figures 1 and 2. Figure 1 demonstrates national waste stream changes since 1980 [DOE 1980-1996]. The trend line in Figure 1 is the best fit of the LLRW data with a projection into the future. The projection that is projected from the best fit of data points for all years continues to decrease; however, actual deliveries in recent years have decreased more rapidly than the projection. The actual annual volume of waste decreased 20 percent in 1995 and 39 percent in 1996.

The national trend is reflected in individual compacts, as can be observed in Figure 2 for the CIC. Like the national trend, there has been a continuing reduction in volume in the CIC Compact due to increased supercompaction and other volume-reduction techniques. In its license application, American Ecology Corporation projected a constant level of LLRW of 55,000 cubic feet per year, as demonstrated by the square dots in Figure 2 [SAR]. However, the diamond-shaped dots in Figure 2 show the actual waste, and the fitted trend line clarifies the precipitous drop in the volume of waste for the CIC states [Hoffman and Hayden 1996, 3]. The expected volumes are such a small fraction of what was originally projected that a CIC facility could not be economical under these circumstances. The disposal fee necessary to cover the accumulating costs is projected to be in excess of $\$ 18,500$ per cubic foot if the facility opened in January 2002 [Hayden and Bolduc, forthcoming]. Yet, national studies indicate no generator would pay more than a few hundred dollars per cubic foot. Barnwell and Envirocare currently charge a small fraction of the cost projected for the American Ecology Corporation facility planned for the CIC.

\section{Excess Capacity of Current Commercial System}

With waste streams falling since 1980 , the disposal capacity of the commercial waste system has been extended. There are currently three commercial sites: Barn- 
Figure 1. National LLRW, 1980-1996. Trend Projection, 1997-2002

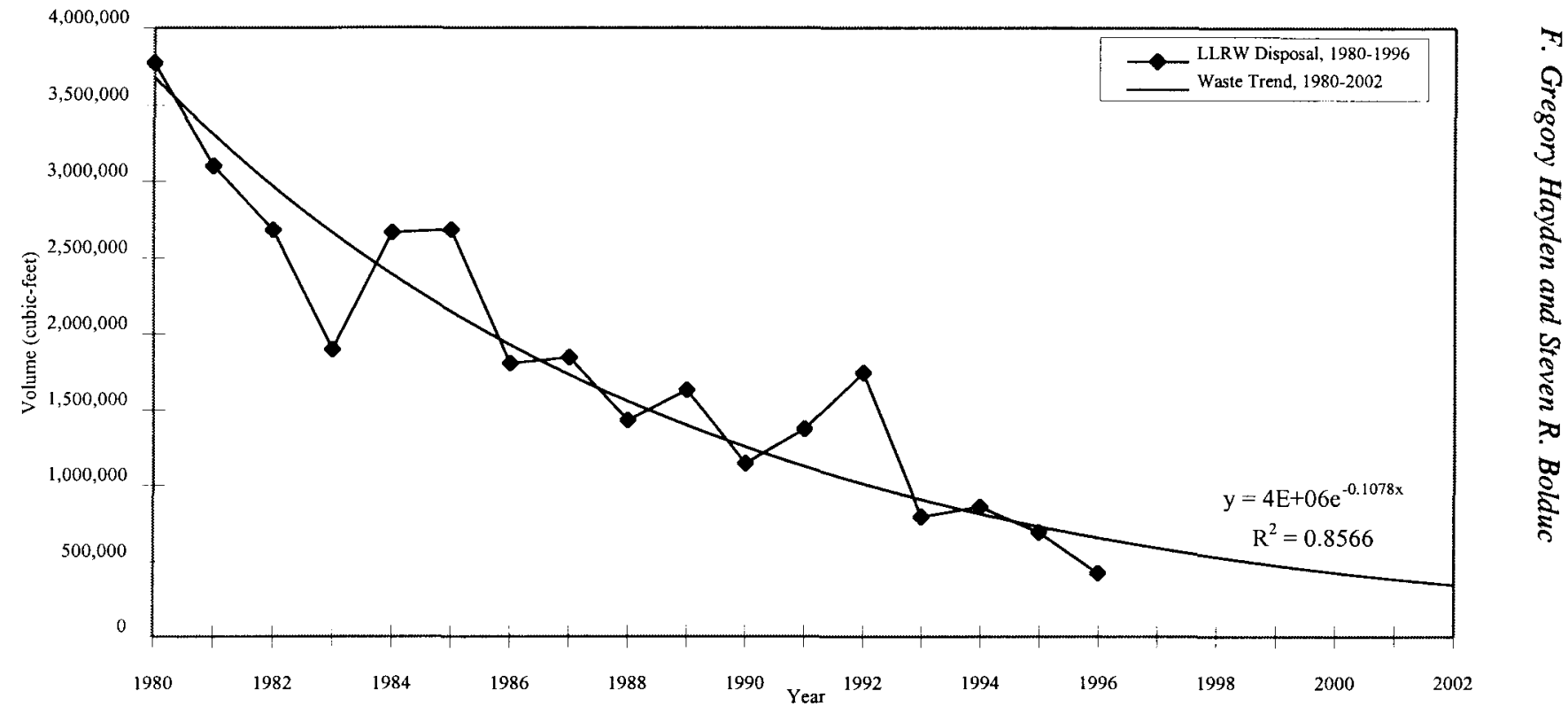


Figure 2. CIC States LLRW, 1986-1995. Trend Projections, 1996-2002

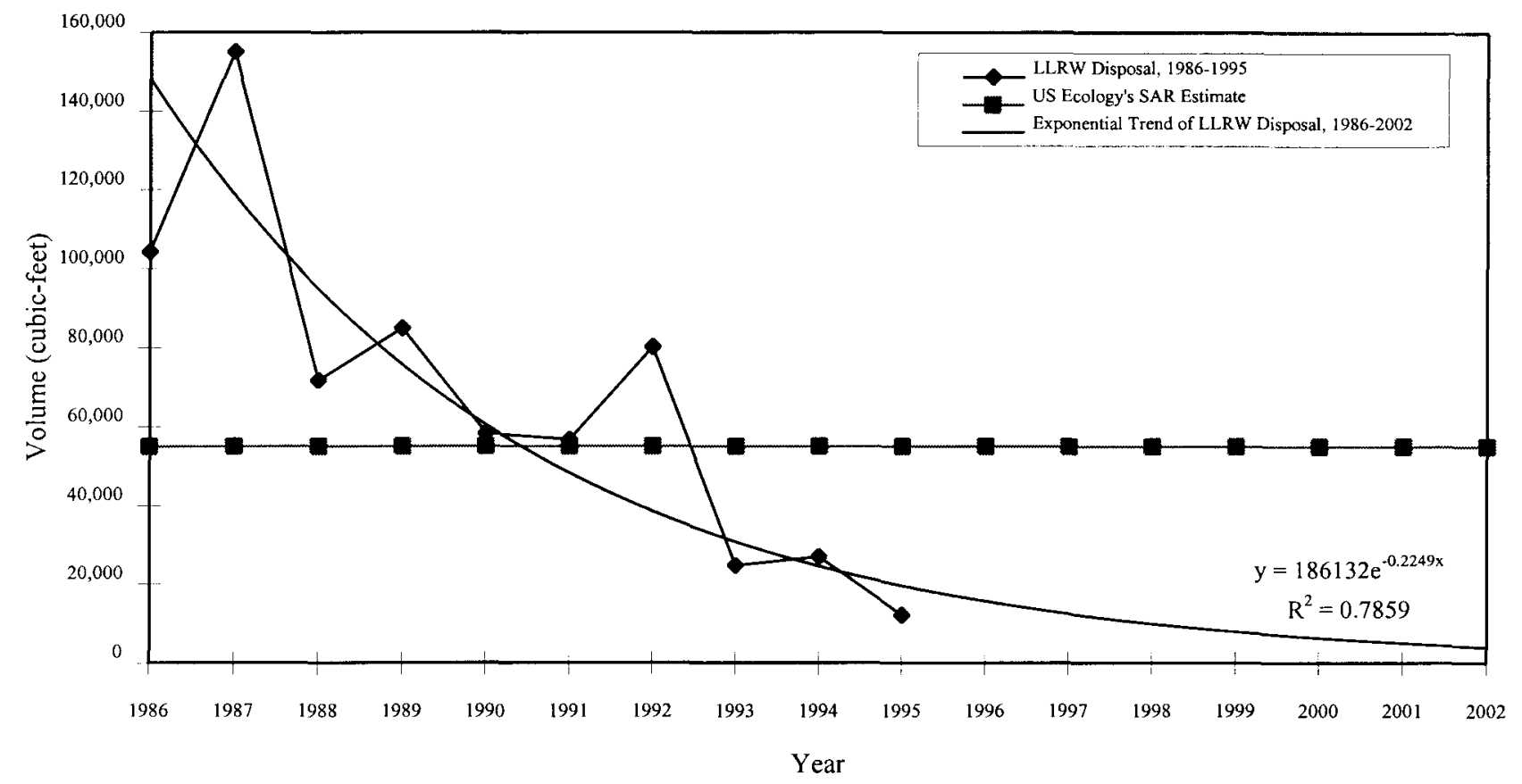


well, South Carolina; Richland, Washington; and Clive, Utah. The Barnwell facility, operated by Chem-Nuclear Systems, is open to accept LLRW from 49 states. Without any further reduction in waste volume, Barnwell has approximately 29 years of capacity for the 49 states it serves ["Chem-Nuclear . . ." 1997]. The Richland facility, operated by American Ecology Corporation, accepts waste from 11 states. The Washington Department of Health has estimated that, without any further waste volume reduction, Richland has approximately 300 years of capacity for the 11 states it serves [Strong 1994, 3]. The Department of Energy has not published data for the Clive facility owned by Envirocare. Envirocare executives estimate about 47 years of future capacity [Rafati 1997].

The capacity conclusion is clear: there is already excess disposal capacity without the creation of any new waste sites, while at the same time waste volumes continue to fall.

\section{Review of Findings and Conclusion}

Let us review: in the face of (1) decreasing volumes of waste, (2) technological advancements for LLRW reduction, (3) excess disposal capacity, (4) excessive expenditures due to cost-plus contracts, (5) nothing being built, (6) projected costs for a new disposal facility that would be too expensive for utilization, and (7) a current waste system that cannot accommodate additional disposal facilities without financial failures - in the face of such a reality-the subgovernment continues to renew contracts and spend funds required from those contracts. That is not a reality consistent with the demise of a subgovernment; it is a reality consistent with the subgovernment moving its decision making outside of Washington, D.C., and successfully managing to function against a disaggregated and underfunded opposition.

The CIC fits the criteria explained earlier for judging the existence of a subgovernment. First, complementary goals exist among the associated parties, and there is a high degree of cooperation. Second, the actors share a policy monopoly that establishes and protects the shared interests of the small group of actors. Third, contracts and agreements are renewed by quiet negotiations outside the public glare of CIC Commission meetings. The generators and development corporations establish their own contractual terms, which are then approved by the commissioners. Fourth, policy shifts are avoided. The lucrative contract terms are left the same, while the dollar levels are increased. Fifth, emphasis is placed on redistribution of income to the subgovernment actors because distributive issues allow greater stability for the subgovernment due to the low visibility to the public of income flows. Finally, and most importantly, the CIC subgovernment is so powerful that it can continue to dominate in the face of an obvious reality in which new waste facilities are not needed. Therefore, the conclusion is that the context studied here does not demonstrate a demise in the nuclear energy subgovernment. 


\section{References}

Baumgartner, Frank R., and Bryan D. Jones. Agendas and Instability in American Politics. Chicago: University of Chicago Press, 1993.

Berry, Jeffrey M. "Subgovernments, Issue Networks, and Political Conflict." In Remaking of American Politics, edited by R. A. Harris and S. M. Milkis. Boulder, Colo.: Westview Press, 1989.

Campbell, John L. Collapse of an Industry: Nuclear Power and the Contradictions of U.S. Policy. Ithaca, N.Y.: Cornell University Press, 1988.

"Chem-Nuclear Explores Options for Meeting South Carolina Revenue Requirements." LLW Notes (August/September 1997).

Del Sesto, Steven L. Science Politics and Controversy: Civilian Nuclear Power in the United States, 1946-1974. Boulder, Colo.: Westview Press, 1979.

Duffy, Robert J. Nuclear Politics in America: A History and Theory of Government Regulation. Lawrence: University of Kansas Press 1997.

Hayden, F. Gregory, and Steven R. Bolduc. "Political and Economic Analysis of Low-Level Radioactive Waste." Journal of Economic Issues 31 (June 1997): 605-613.

Hoffman, D. Jay, and F. Gregory Hayden. Waste Stream Analysis of the Proposed Low-Level Radioactive Waste Site in Boyd County, Nebraska. Lincoln: Office of Nebraska Commissioner, Central Interstate Low-Level Radioactive Waste Compact, Summer 1996.

Lowi, Theodore J. "American Business, Public Policy, Case Studies, and Political Theory." World Politics 16 (1964): 677-715.

McCool, Daniel. "Subgovernments as Determinants of Political Viability." Political Science Quarterly 105 (1990): 269-293.

Melman, Seymour. "From Private to State Capitalism: How the Permanent War Economy Transformed the Institutions of American Capitalism." Journal of Economic Issues 31(June 1997): 311-330.

Rafati, Al. Interviews with Envirocare's Vice-President of Marketing/Business Development who is familiar with the data, 1997.

Safety Analysis Review, Rev 8. (SAR). License Application submitted by American Ecology Corporation to Nebraska Department of Environmental Quality, Lincoln, Nebraska.

Strong, T. R. Repont Prepared for the Nuclear Waste Advisory Council. Department of Health, Division of Radiation Protection, Olympia, Wash.: State of Washington, 1994.

Temples, James R. "The Politics of Nuclear Power: A Subgovernment in Transition." Political Science Quarterly 95 (1980): 239-260.

U.S. Department of Energy (DOE). "Capacity of U.S. Commercial Low-Level Radioactive Waste Disposal." Annual State-by-State Assessment of LLRW Received at Commercial Disposal Sites. Washington, D.C.: DOE, 1997.

U.S. General Accounting Office (GAO). Contract Reform Is Progressing, but Full Implementation Will Take Years. GAO/RCED-97-18. Washington, D.C.: GAO, 1997. 